\title{
THE EFFECT OF MUSTARD GAS (DICHLORETHYL- SULPHID) ON EXPERIMENTAL TUBERCULOSIS
}

\author{
H. J. CORPER and O. B. Rensch
}

From the Reseach Department, National Jewish Hospital for Consumptives, Denver, Colo.

There immediately arose as a result of the use of mustard gas in warfare, the question of the effect of this substance on the respiratory tract and its diseases. The universal prevalence of tuberculosis either in the latent or active form, made this question one of great importance. However, like all questions pertaining to pulmonary tuberculosis, the answer is complicated by many factors which, though capable in sum total or individually of affecting the disease indirectly by lowering the general vitality, by hastening dissemination, etc., have no direct or primary effect on tuberculosis.

Clinical reports have indicated in some cases a harmful, ${ }^{1}$ and in others a negligible, ${ }^{2}$ effect from gassing on existing and dormant pulmonary tuberculosis.

It is interesting in this connection that tuberculosis in the animal is not perceptibly influenced by agents and procedures having a profound effect on acute experimental infections. Corper and Chovey ${ }^{3}$ found that mice subjected to a single nonlethal exposure to the roentgen ray, capable however of producing a leukopenia, or given a nonfatal injection of thorium $\mathrm{X}$, also capable of causing leukopenia, and shortly thereafter inoculated with pneumococci or hemolytic streptococci, human and bovine, revealed an increased susceptibility to all of these organisms, as indicated by an increased and earlier mortality among the treated animals and the earlier appearance in, and longer persistence of, the cocci in the blood, as compared with animals subjected only to inoculation. Winternitz and his co-workers ${ }^{4}$ found that benzene had a similar effect on pneumococcus infections in rabbits while Läwen ${ }^{5}$ found that prolonged roentgen-ray exposure of rabbits increased their susceptibility to staphylococcus infections, and that the resistance of mice to pyocyaneus and anthrax, and rats to anthrax was reduced by roentgenization. The tubercle bacillus, however, stands out distinctly from these organisms in. respect to the leukotoxic agents as noted by Corper, ${ }^{8}$ Kellert ${ }^{7}$ and Weinberg, ${ }^{8}$ the course

Received for publication Dec. 20, 1920.

1 Riforma med., 1918, 34, p. 2.

2 Paris méd., 1918, 8, p. 17.

3 Jour. Infect. Dis., 1920,27, p. 491.

4 Jour. Exper. Med., 1913, 17, p. 657.

- Mittl. a. d. Grezgebieten der. Med. u. Chir.; 1919, 19, p. 141.

- Amer. Rev. Tuberc., 1918, 2, p. 587.

7 Jour. Med. Res., 1918, 39, p. 93.

8 Arch. Int. Med., 1920, 25, p. 565. 
of tuberculosis in guinea-pigs being uninfluenced by benzene, thorium $\mathrm{X}$ and the roentgen ray. Hektoen and his co-workers ${ }^{2}$ have found that these leukotoxic agents greatly reduce the production of specific antibodies and believe that these substances may lower the anti-infectious powers of the body in at least three ways: by the reduction of antibodies, by the reduction of the number of leukocytes, and by the reduction of the phagocytic activity of the leukocytes.

In some respects mustard gas acts like other leukotoxic agents. Krumbhaar ${ }^{10}$ noted in man, especially in severe or fatal cases of gassing, that at first there is an increase in the circulating leukocytes (in individual cases as high as 36,000 and averaging in his series about 12,000), and if death does not interrupt the downward course of the leukocytes, an extreme degree of leukopenia may be reached. Krumbhaar and Krumbhaar ${ }^{{ }^{11}}$ were able to examine the bone marrow in 55 fatal cases and conclude that mustard gas has a direct toxic action on the bone marrow affecting the hematopoietic cells. They regard the action similar to that of benzene. Pappenheimer and Vance ${ }^{12}$ obtained similar results in rabbits following the intravenous injection of mustard gas, a marked diminution of circulating leukocytes and a specifically poisonous action on the hematopoietic tissues. Hektoen and Corper ${ }^{13}$ corroborated these findings in dogs given mustard gas intravenously and found this substance to have an inhibitory action on the development of specific antibodies in both rabbits and dogs.

The marked toxicity of this substance to the tissues of man and animals - the human eye may react after an exposure of less than one hour to one part in $10,000,000^{14}$ and the skin after an exposure of 30 minutes to $0.02 \mathrm{mg}$. per liter ${ }^{15}$-made it seem desirable to test the tuberculoidal action of dichlorethylsulphid. Since, however, this compound is markedly unstable in aqueous solutions the problem proved to be beset with certain difficulties. Lynch, Smith and Marshall ${ }^{16}$ found that aqueous solutions would hydrolyze to the extent of $15 \%$ in 10 minutes at $10 \mathrm{C}$, while at $37.5 \mathrm{C}$. over $97 \%$ was decomposed in the same time. They found that absolute alcohol solutions of mustard gas were stable. The difficulty of working with tubercle bacilli in alcoholic solutions is obvious, so it was decided to study the effect of mustard gas in glycerol, in which it is fairly soluble, on tubercle bacilli and control the work by tests with glycerol of the same concentration as that used for dissolving the mustard gas. The following experiment may be open to criticisms, but it gives some information on the tuberculocidal action of mustard gas.

\footnotetext{
Jour. Infect. Dis., 1916,19 , p. $69 ; 1915,17$, p. 415;1918, 22, p. 28; 1920, 26, p. 330.

10 Jour. Amer. Med. Assn., 1919, 72, p. 39.

11 Jour. Med. Res., 1919, 40, p. 497.

12 Jour. Exper. Med., 1920, 31, p. 72.

13 Jour. Infect. Dis.

14 Jour. Pharm. \& Exper. Therap., 1920, 15, p. 77.

15 Ibid., 1920, 15, p. 95.

18 Ibid., 1918-19, 12, p. 265.
} 
Actively growing cultures of human, avirulent and virulent, and bovine tubercle bacilli were well ground up in a small amount of sterile $0.9 \%$ sodium chloride solution and were then added to varying dilutions of sterile glycerol (25 and $50 \%$ ) in $0.9 \%$ sodium chloride solution, and to dilutions of mustard gas in $25 \%$ glycerol ranging from 0.1 to $0.000,000,1 \%$. The mustard gas solutions were prepared from a fresh $2 \%$ alcoholic solution of mustard gas. The suspension was well mixed, placed in the incubator for the intervals over 5 minutes and at room temperature for the shorter periods, and after a definite time a certain amount of the mixture was withdrawn, about 0.5 to $1 \mathrm{cc}$, and put into about 10 to $15 \mathrm{c} \mathrm{c}$ of sterile $0.9 \%$ sodium chloride solution, well shaken and centrifugated at high speed to sediment the tubercle bacilli, after which they were carried through the $3 \%$ sodium hydroxide procedure described by Petroff ${ }^{17}$ and seeded on gentian violet egg medium. Two or more culture tubes were seeded for each time interval and from each dilution of glycerol and mustard gas. The results of this experiment are given in table 1.

TABLE 1

Tuberculocidal Action of Mustard Gas (Dichlorethylsulphid) for Human and Bovine Bacilit

\begin{tabular}{|c|c|c|c|c|c|c|c|c|}
\hline \multirow[t]{2}{*}{ Culture } & \multirow{2}{*}{$\begin{array}{l}\text { Period of } \\
\text { Action }\end{array}$} & \multicolumn{2}{|c|}{$\begin{array}{l}\text { Controls in } \\
\text { Glycerol }\end{array}$} & \multicolumn{5}{|c|}{$\begin{array}{l}\text { Dilutions: Percentage of Mustard Gas in } 25 \% \\
\text { Glycerol in } 0.9 \% \text { NaCl Solution }\end{array}$} \\
\hline & & $25 \%$ & $50 \%$ & 0.1 & 0.01 & 0.001 & 0.00001 & 0.0000001 \\
\hline $\begin{array}{l}\text { Human } \\
\text { Avir- } \\
\text { ulent }\end{array}$ & $\begin{array}{l}1 \text { minute } \\
5 \text { minutes } \\
30 \text { minutes } \\
2 \text { hours } \\
4 \text { hours } \\
1 \text { day } \\
1 \text { week }\end{array}$ & $\begin{array}{l}+^{*} \\
+ \\
+ \\
+ \\
+ \\
+ \\
+\end{array}$ & $\begin{array}{l}+ \\
+ \\
\pm \\
= \\
=\end{array}$ & $\begin{array}{l}+ \\
+ \\
+ \\
+ \\
= \\
+\end{array}$ & $\begin{array}{l}+ \\
+ \\
+ \\
+ \\
+ \\
+\end{array}$ & $\begin{array}{l}+ \\
+ \\
+ \\
+ \\
+ \\
+\end{array}$ & $\begin{array}{l}+ \\
+ \\
+ \\
+ \\
+ \\
+ \\
+\end{array}$ & $\begin{array}{l}+ \\
+ \\
+ \\
+ \\
+ \\
+ \\
+\end{array}$ \\
\hline $\begin{array}{c}\text { Human } \\
\text { lent }\end{array}$ & $\begin{array}{l}1 \text { minute } \\
5 \text { minutes } \\
30 \text { minutes } \\
2 \text { hours } \\
4 \text { hours } \\
1 \text { day } \\
1 \text { week }\end{array}$ & $\begin{array}{l}+ \\
+ \\
+ \\
+ \\
+ \\
-\end{array}$ & $\begin{array}{l}+ \\
\pm \\
= \\
= \\
= \\
=\end{array}$ & $\begin{array}{l}+ \\
\pm \\
= \\
=\end{array}$ & $\begin{array}{l}+ \\
+ \\
\pm \\
= \\
=\end{array}$ & $\begin{array}{l}+ \\
+ \\
+ \\
+ \\
+ \\
-\end{array}$ & $\begin{array}{l}+ \\
+ \\
+ \\
+ \\
+ \\
+ \\
-\end{array}$ & $\begin{array}{l}+ \\
+ \\
+ \\
+ \\
+ \\
+ \\
-\end{array}$ \\
\hline Bovine & $\begin{array}{l}1 \text { minute } \\
5 \text { minutes } \\
30 \text { minutes } \\
2 \text { hours } \\
4 \text { hours } \\
1 \text { day } \\
1 \text { week }\end{array}$ & $\begin{array}{l}+ \\
+ \\
+ \\
+ \\
+ \\
+\end{array}$ & $\begin{array}{l}+ \\
+ \\
+ \\
\pm \\
=\end{array}$ & $\begin{array}{l}+ \\
+ \\
+ \\
+ \\
+ \\
+\end{array}$ & $\begin{array}{l}+ \\
+ \\
+ \\
+ \\
+ \\
+ \\
+\end{array}$ & $\begin{array}{l}+ \\
+ \\
+ \\
+ \\
+ \\
+ \\
+\end{array}$ & $\begin{array}{l}+ \\
+ \\
+ \\
+ \\
+ \\
+\end{array}$ & $\begin{array}{l}+ \\
+ \\
+ \\
+ \\
+ \\
+\end{array}$ \\
\hline
\end{tabular}

* Two or more culture tubes were seeded at each interval from each dilution.

Table 1 reveals that dissolved in 25\% glycerol mustard gas is bactericidal toward tubercle bacilli only after at least 30 minutes'

17 Jour. Exper. Med., 1915, 21, p. 38, and Corper, H. J., Fiala, L.. and Kallen, Lincoln, Jour. Infect. Dis., 1918, 23, p. 267. 
exposure to $0.1 \%$ and after 2 hours or more to $0.01 \%$. These results were obtained with virulent human tubercle bacilli. They seem to be slightly more sensitive than avirulent human and bovine tubercle bacilli; the latter two cultures requiring from 4 hours' to 1 day's exposure to obtain the same effect. What part, favorable or inhibitory, the glycerol may have played remains undetermined from these experiments, although it would seem from the tests with glycerol alone that the tendency might be to enhance the action of the mustard gas on the bacilli. That mustard gas in higher concentrations dissolved in $25 \%$ glycerol will kill tubercle bacilli is brought out further by the animal experiments.

In previously reported experiments on the influence of certain agents. on the resistance of guinea-pigs to tuberculosis, ${ }^{18}$ it was found that certain local irritants-turpentine, croton oil, tincture of cantharidin and tincture of capsicum-had no appreciable influence on the progress of the experimental infection in this animal, while lamp black had a distinctly retarding influence, and finely pulverized glass a markedly accelerating influence when injected with the bacilli. Krause and Willis ${ }^{19}$ recently found that the degree of allergy and immunity of guinea-pigs with an existing tuberculous focus are reduced at the site of an inflammatory tuberculin reaction for at least 4 days after the application of tuberculin. It seemed desirable, therefore, to study the local as well as the general effect of mustard gas on experimental tuberculosis, and the following experiments were devised with this in mind.

A series of guinea-pigs were infected with varying amounts of virulent human tubercle bacilli (culture Maxfield), 0.000,01, 0.000, $.000,1$ and $0.000,000,001 \mathrm{mg}$; 9 guinea-pigs of the series served as controls, 3 receiving the same amount of a uniform suspension of the tubercle bacilli subcutaneously into the left lower quadrant of the abdomen; 9 received the bacilli in $0.5 \mathrm{c} c$ of $0.9 \%$ sodium chloride solution mixed with $0.5 \mathrm{cc}$ of $0.2 \%$ mustard gas in sterile $50 \%$ glycerol, the solution being injected subcutaneously within 10 minutes after mixing; and 9 others received the bacilli in $0.5 \mathrm{cc}$ of $0.9 \%$ saline solution mixed with $0.5 \mathrm{cc}$ of $0.02 \%$ mustard gas in sterile $50 \%$ saline solution results of this experiment are given in table 2 . 
TABLE 2

The Results of the Subcutaneous Injection of Mustard Gas Mixed with a Suspension of Tubercle Bacilli on the Developaent of TUberculosis in the Guinea-Pig

\begin{tabular}{|c|c|c|c|}
\hline \multirow[b]{2}{*}{$\begin{array}{l}\text { The Amount of } \\
\text { 'Iubercle Bacilli } \\
\text { Injested, } \\
\text { Mg. }\end{array}$} & \multicolumn{3}{|c|}{ The Amount of Tuberculosis Found in the Guinea-Pig } \\
\hline & $\begin{array}{l}\text { Controls } \\
\text { Given the } \\
\text { Bacilli } \\
\text { Alone }\end{array}$ & $\begin{array}{l}\text { Animals Given the } \\
\text { Bacilli }(0.5 \mathrm{cc})+ \\
(0.5 \mathrm{c} \text { c) } 0.2 \% \text { Mustard } \\
\text { Gas in } 50 \% \text { Glycerol }\end{array}$ & $\begin{array}{l}\text { Animals Given the } \\
\text { Bacilli }(0.5 \mathrm{c} \text { c) }+ \\
(0.5 \mathrm{c} \mathrm{c}) 0.02 \% \text { Mustard } \\
\text { Gas in } 50 \% \text { Glycerol }\end{array}$ \\
\hline 0.00001 & $\begin{array}{c}++^{*} \\
+++ \\
++\end{array}$ & $\begin{array}{l}-t \\
-t\end{array}$ & $\begin{array}{l}++ \\
++ \\
++\end{array}$ \\
\hline 0.0000001 & $\begin{array}{l}+ \\
+ \\
+\end{array}$ & $\begin{array}{l}- \\
-t \\
-t\end{array}$ & $\begin{array}{l}-+ \\
-\end{array}$ \\
\hline 0.000000001 & $\overrightarrow{+}$ & $\begin{array}{l}-1 \\
-\end{array}$ & $\begin{array}{c}{ }_{t}^{\dagger} \\
\text { died }\end{array}$ \\
\hline
\end{tabular}

* All the guinea-pigs recorded were sectioned 5 weeks after injection. Those that died before this time are marked died. The markings are graded (from - to ++++ ) on the basis of the amount of anatomic tuberculosis found in the guinea-pigs.

+ All the guinea-pigs recorded with $a+$ after the anatomic grading developed discharging ulcers at the site of injection, while those not thus marked did not develop ulcers.

$+=$ Distinctly enlarged local and slightly enlarged retroperitoneal glands.

$++\equiv$ Enlarged local and retroperitoneal glands and slight involvement of spleen.

$+++=$ Enlarged local and retroperitoneal glands, spleen markedly involved, the peritracheal glands enlarged and the lungs slightly involved.

$++++=$ Massive involvement of all glands, spleen, lungs and liver.

TABLE 3

The Effect of Mustard Gas Given Subcutaneousi.y on the Progress of the Tuberculosis in Guinea-Pigs Resulting from the Subcutaneotes Injection of Virulent Human Tubercle Bacilli

\begin{tabular}{|c|c|c|c|c|c|}
\hline \multirow{2}{*}{$\begin{array}{c}\text { The Amount } \\
\text { of Tubercle } \\
\text { Bacilli } \\
\text { Injected, } \\
\text { Mg. }\end{array}$} & \multirow{2}{*}{$\begin{array}{l}\text { Controls } \\
\text { Given the } \\
\text { Bacilli Alone } \\
\text { in } 0.9 \% \\
\text { Na. }\end{array}$} & \multirow{2}{*}{$\begin{array}{c}\text { Controls Given } \\
\text { the Bacilli } \\
\text { Alone in } 50 \% \\
\text { Glycerol } \\
\text { Immediately } \\
\text { After Mixing }\end{array}$} & \multicolumn{3}{|c|}{$\begin{array}{c}\text { Guinea-Pigs Treated by a Single } \\
\text { Subcutaneous Injection of } \\
0.5 \text { c ef of Mustard Gas in } \\
50 \% \text { Glycerol }\end{array}$} \\
\hline & & & $0.5 \%$ & $0.2 \%$ & $0.02 \%$ \\
\hline 0.1 & $\begin{array}{l}+++* \\
+++ \\
+++ \\
+++\end{array}$ & $\begin{array}{l}+++ \\
+++ \\
+++ \\
+++\end{array}$ & All died & $\begin{array}{l}++++ \\
++ \\
+++ \\
\text { Died }\end{array}$ & $\begin{array}{l}+++ \\
+++ \\
+++ \\
+++\end{array}$ \\
\hline 0.001 & $\begin{array}{l}++ \\
+++ \\
++ \\
++\end{array}$ & $\begin{array}{l}++ \\
++ \\
+++ \\
+++\end{array}$ & All died & $\begin{array}{l}+++ \\
++ \\
++ \\
++\end{array}$ & $\begin{array}{l}++ \\
++t \\
++t \\
++t\end{array}$ \\
\hline 0.00001 & $\begin{array}{l}++ \\
++ \\
++ \\
++\end{array}$ & $\begin{array}{l}++ \\
+ \\
++ \\
++ \\
\end{array}$ & All died & $\begin{array}{c}++ \\
+ \\
+ \\
\text { Died }\end{array}$ & $\begin{array}{l}+ \\
++ \\
++ \\
++\end{array}$ \\
\hline 0.0000001 & $\begin{array}{l}++ \\
++ \\
++ \\
+\end{array}$ & $\begin{array}{l}++ \\
+ \\
+ \\
+\end{array}$ & All died & $\begin{array}{c}++ \\
+ \\
\text { Died } \\
\text { Died }\end{array}$ & $\begin{array}{l}++ \\
++ \\
+ \\
++\end{array}$ \\
\hline
\end{tabular}

* See note to table 2 for the significance in anatomic tuberculous involvement of the markings - to ++++ . These animals were all examined 4 weeks after infection.

+ Two of each set of 4 of the animals treated with mustard gas received the injection subcutaneously in the right half of the abdomen and the other 2 subeutaneously in the region of the chest. 
From this experiment it seems justifiable to conclude that tubercle bacilli in $0.1 \%$ mustard gas in $25 \%$ glycerol injected subcutaneously into guinea-pigs are not capable of causing systemic tuberculosis, likewise even $0.01 \%$ mustard gas has a distinctly retarding influence on the infection not to be explained by the sloughing out of bacilli resulting from the destructive action of the mustard gas on the animal tissues, since the same effect was noted where no ulcers developed.

In order to determine whether mustard gas given to guinea-pigs injected with tubercle bacilli had any general effect, either retarding or hastening the progress of the resulting tuberculosis, a series of guinea-pigs of uniform size-all males-were infected with different amounts of a uniform suspension ${ }^{20}$ of virulent human tubercle bacilli -culture Maxfield-ranging from 0.1 to $0.000,000,1 \mathrm{mg}$. by subcutaneous injection and were then given a single subcutaneous injection of mustard gas in $50 \%$ glycerol $-0.5 \mathrm{c}$ c of $0.5,0.2$ or $0.02 \%$. The results of this experiment are given in table 3 .

The results obtained in this experiment indicate that mustard gas injected subcutaneously into guinea-pigs in an amount just below $(0.5 \mathrm{c} c$ of $0.2 \%)$ the lethal dose $(0.5 \mathrm{cc}$ of $0.5 \%)$ or less $(0.5 \mathrm{cc}$ of $0.02 \%$ ), about one-tenth the lethal dose, has no appreciable influence on the tuberculosis in these animals resulting from the subcutaneous injection of different amounts (from 0.1 to $0.000,000,1 \mathrm{mg}$.) bacilli, as is determined by the anatomic distribution of the tuberculosis involvement.

In a small series of animals tested in preliminary experiments there seemed to be a retarding influence on the tuberculosis by the glycerolmustard gas mixture given subcutaneously. Since the $50 \%$ glycerol used in this experiment had been boiled for a considerable time, it seemed desirable to repeat this experiment on a larger scale and also to test further the mustard gas $(0.5 \mathrm{cc} 0.2 \%)$ in $50 \%$ glycerol, the latter having been sterilized by only a short period of boiling or autoclaving. One set of guinea-pigs was given a single injection and another set repeated injections ( 3 or 4 injections spaced at 4 day intervals); likewise $50 \%$ glycerol which had been boiled for about 30 minutes to one hour, in which time a decided yellow color develops in the solution, was used for treatment and one set of the animals was given a single injection and another set 3 or 4 injections spaced at 4 day intervals. The guinea-pigs were infected by the subcutaneous injection of a uniform suspension of a culture (No. 1851) of virulent

${ }^{20}$ Jour. Infect. Dis., 1918, 23, p. 500. 
human tubercle bacilli into the left lower quadrant of the abdomen. The glycerol and mustard gas was injected subcutaneously into the right half of the abdomen. The results of this experiment are given in table 4.

TABLE 4

The Effect of the Repeated Subcutaneous Injection of Nonlethal Amounts of Mustard Gas and Boiled Glycerol on Tuberculosis in the Guinea-Pig

\begin{tabular}{|c|c|c|c|c|c|}
\hline \multirow{2}{*}{$\begin{array}{c}\text { Amount } \\
\text { of } \\
\text { Tubercle } \\
\text { Bacilli } \\
\text { Injected, } \\
\text { Mg. }\end{array}$} & \multirow{2}{*}{$\begin{array}{c}\text { Controls } \\
\text { Given } \\
\text { the } \\
\text { Bacilli } \\
\text { in } 0.9 \% \\
\text { NaCl }\end{array}$} & \multicolumn{2}{|c|}{$\begin{array}{l}\text { Boiled Glycerol } \\
50 \%(0.5 \text { c e) Given } \\
\text { Subcutaneously }\end{array}$} & \multicolumn{2}{|c|}{$\begin{array}{l}\text { Mustard Gas in } 50 \% \\
\text { Sterile Glycerol. 0.5 e e of } 0.2 \% \\
\text { Given Subcutaneously }\end{array}$} \\
\hline & & $\begin{array}{l}\text { Single } \\
\text { Injection }\end{array}$ & $\begin{array}{l}\text { Repeated } \\
\text { Injections } \\
\text { at 4-Day } \\
\text { Intervals } \\
\text { for } 3 \text { or } 4 \\
\text { Injections }\end{array}$ & $\begin{array}{l}\text { Single } \\
\text { Injection }\end{array}$ & $\begin{array}{l}\text { Repeated } \\
\text { Injections } \\
\text { at 4-Day } \\
\text { Intervals } \\
\text { for } 3 \text { or } 4 \\
\text { Injections }\end{array}$ \\
\hline 0.001 & $\begin{array}{l}+++^{*} \\
+++ \\
+++ \\
+++ \\
+++ \\
+++\end{array}$ & $\begin{array}{c}++++ \\
+++ \\
+++ \\
1 \text { died }\end{array}$ & All Died $\dagger$ & $\begin{array}{l}+++ \\
+++ \\
+++ \\
++\end{array}$ & $\begin{array}{l}+++ \\
+++ \\
2 \text { died }\end{array}$ \\
\hline 0.00001 & $\begin{array}{c}+++ \\
++ \\
++ \\
++ \\
+++ \\
1 \text { died }\end{array}$ & $\begin{array}{c}+++ \\
++ \\
++ \\
1 \text { died }\end{array}$ & $\begin{array}{c}++ \\
++ \\
2 \text { died }\end{array}$ & $\begin{array}{c}++ \\
+ \\
++ \\
1 \text { died }\end{array}$ & $\begin{array}{l}++ \\
++ \\
2 \text { died }\end{array}$ \\
\hline 0.0000001 & $\begin{array}{l}++ \\
+ \\
++ \\
+ \\
+\end{array}$ & $\begin{array}{c}++ \\
+ \\
+ \\
1+d e d\end{array}$ & $\begin{array}{c}+ \\
++ \\
+ \\
1 \text { died }\end{array}$ & $\begin{array}{c}+ \\
+ \\
1 \stackrel{+}{+} \\
\text { died }\end{array}$ & All died \\
\hline
\end{tabular}

* The gujnea-pigs in this experiment were examined 4 weeks after infection. The markings from - to ++++ designate the amount of tuberculosis found, as indicated in the footnote to table 2 .

$f$ The boiled glycerol tended to produce large ulcers which proved fatal to the guinea-pigs, especially those given repeated injections.

The experiments given in table 4 seem to indicate that even repeated subcutaneous injections ( 3 to 4 at 4-day intervals), consistent with the life of the guinea-pig, of a barely nonlethal dose of mustard gas in sterile $50 \%$ glycerol has no appreciable effect on the progress of the tuberculosis in these animals, as indicated by the anatomic distribution resulting from the subcutaneous injection of virulent human tubercle bacilli in amounts ranging from 0.001 to $0.000,000,1 \mathrm{mg}$. of a uniform suspension in $0.9 \%$ sodium chloride solution. Glycerol $50 \%$ in a $0.9 \%$ sodium chloride solution boiled for about one hour until it has a distinct yellow tint and given subcutaneously in amounts of $0.5 \mathrm{cc}$ repeated 3 or 4 times at intervals of 4 days has likewise no appreciable effect on the anatomic distribution of the tuberculosis resulting from 
the subcutaneous injection of virulent human tubercle bacilli in guineapigs, although glycerol has a marked local destructive action on the tissues.

\section{SUMMARY AND CONCLUSIONS}

Mustard gas dissolved in 25\% glycerol is bactericidal toward virulent human tubercle bacilli after an exposure in vitro of at least onehalf hour to $0.1 \%$ and after 2 hours to $0.01 \%$. Avirulent human and bovine tubercle bacilli seem to be slightly less sensitive, these organisms requiring an exposure of from 4 hours to 1 day to obtain the same results. What part, if any, the hydrolysis of mustard gas in the glycerol played in this experiment was not determined.

Mustard gas in $0.1 \%$ strength in $25 \%$ glycerol containing virulent human tubercle bacilli and injected immediately subcutaneously into guinea-pigs entirely prevented the development of systemic tuberculosis in these animals; even $0.01 \%$ mustard gas has a distinct retarding influence on the development of tuberculosis in these animals. This action could not be due to the tissue destructive action of the mustard gas in these concentrations, since the same results were obtained in the absence of ulcers.

Mustard gas given subcutaneously to guinea-pigs in amounts consistent with life $(0.001 \mathrm{c}$ c in glycerol) in a single injection or repeated, at 4-day intervals for 3 or 4 injections, has no appreciable effect on the amount of anatomic tuberculosis resulting from the subcutaneous injections of virulent human tubercle bacilli. 